\title{
HABITAT TYPES - WHAT THEY CAN TELL US NOW AND IN THE FUTURE
}

\author{
WindMULLER-CAMPIONE, M.A. ${ }^{1,3 *}$-KOTAR, J. ${ }^{2}-$ NAGEL, N.M. ${ }^{1,4}$ \\ ${ }^{1}$ School of Forest Resources and Environmental Science, Ecosystem Science Center, \\ Michigan Technological University, Houghton, MI 49930, USA \\ ${ }^{2}$ Terra Silva Forestry Consultants, Eau Claire, WI 54703, USA \\ ${ }^{3}$ Present Address: Department of Wildland Resources, Utah State University, \\ Logan, UT 84322, USA \\ (phone: +1-847-772-5458; fax: +1-435-797-2443) \\ ${ }^{4}$ Present Address: Department of Forest Resources, University of Minnesota, St. Paul, MN \\ *Corresponding author \\ e-mail: marcella.campione@aggiemail.usu.edu \\ (Received $9^{\text {th }}$ Feb 2015; accepted $9^{\text {th }}$ Mar 2015)
}

\begin{abstract}
Habitat classification systems utilize the relationship between the herbaceous layer and potential climax vegetation to classify forest vegetation. Habitat classification systems have been developed throughout the United States including Michigan. In 2010, ten years after the first sampling, 30 of the original 200 plots throughout the Western Upper Peninsula were resampled twice during the growing season. Exotic earthworm populations were also sampled in early September at all 30 plots. Nonmetric multidimensional scaling (NMS) ordination was used to discern differences in habitat types between years (2000 vs. 2010) and between seasons in 2010 (spring vs. summer). Overstory trees per hectare (TPH) decreased from 2000 to 2010, likely the result of forest management activities. A greater number of herbaceous species were observed in 2010; however, the majority of these new species were weedy or invasive. Exotic European earthworms were observed in all habitat types; earthworm densities generally increased with increasing soil richness and site quality, with herbaceous plant cover negatively associated with earthworm biomass. Continual monitoring of these plots will allow scientists and managers to assess how herbaceous community change through time and observe the effects of invasive species and changing climatic patterns on forest ecosystems of the Great Lakes region. Keywords: exotic earthworms, herbaceous species, forest dynamics, Great Lakes Region, forest management
\end{abstract}

\section{Introduction}

Every forest ecosystem is distinct and requires individual consideration when developing management options. Scientists and managers often classify forests with similar attributes to help guide management decisions and to allow for comparisons when different variables are manipulated. Forest classification systems range from the use of one variable (e.g., dominant overstory vegetation to characterize forest cover type) to the use of many complex variables including climate, soils, geology, and vegetation cover (as used in the Terrestrial Ecological Unit Inventory (TEUI); Winthers et al., 2005). Habitat typing was first developed in the Western United States and relies on the presence/absence of particular herbaceous species (see Daubenmire and Daubenmire, 1968). This system of classification was later developed for the Great Lakes region by sampling plots across the Upper Peninsula of Michigan and Northern Wisconsin (Coffman et al., 1983). Further sampling of the Upper and Lower Peninsulas 
of Michigan allowed for the development of The Guide to Forest Communities and Habitat Types of Michigan (Burger and Kotar, 2003).

Early habitat classification systems utilized key concepts from both Clements' (1916, 1936) and Gleason's (1926) theories of vegetation development (Daubenmire, 1976). Habitat typing relies on the early stabilization of the understory, especially the herbaceous layer, compared to the overstory (Daubenmire and Daubenmire, 1968; Pfister and Arno, 1980; Kotar, 1986; Pfister, 1989). This stabilized understory is used to predict the potential climax overstory (resulting in the habitat type name), which is thought to reflect the growth potential of the site (Daubenmire and Daubenmire, 1968; Pfister, 1989). Habitat typing does not view succession as a unidirectional process (Clements, 1916; Clements, 1936) but rather, one that is affected by environmental variables and disturbance history (Daubenmire, 1976).

The concept of habitat typing contains many assumptions about sampling, species interactions, and how species respond to disturbance (see Daubenmire and Daubenmire, 1968; Daubenmire, 1976; Pfister and Arno, 1980; Cook, 1995 for a critical review). Studies within the Great Lakes Region have observed varying responses of the herbaceous layer to disturbance (Metzger and Schultz, 1984; Fredericksen et al., 1999; Jenkins and Parker, 1999; Scheller and Mladenoff, 2002; Zenner et al., 2006; Kern et al., 2006), suggesting potential implications to how this vegetation layer is used to classify site potential. Metzger and Schultz (1981) observed in a northern hardwood forest in the Upper Peninsula of Michigan no large differences in the herbaceous layer between different harvest intensities after 50 years. They did note that spring ephemerals may be more sensitive to repeated disturbances such as single-tree selection. However, Roberts and Gilliam (1995) observed in Northern Lower Michigan a greater change in overall diversity and species composition in disturbed mesic sites than dry/mesic sites when comparing them to undisturbed mesic and dry/mesic sites. The disturbed mesic sites had greater increases in weedy and early successional species. This trend of increasing weedy and early successional species was also observed in mesic northern hardwood forests receiving uneven- aged management compared with even-aged management and old-growth stands in Northern Wisconsin and the Upper Peninsula of Michigan (Scheller and Mladenoff, 2002).

Disturbance is only one factor that can affect herbaceous species composition. Native and exotic species interactions have also been shown to be important (Bohlen et al., 2004; Fisichelli et al., 2012). The introduction of European earthworms in the Great Lakes region, a region that developed without native earthworms following the last glaciation (James, 1995), has not only affected soil nutrient cycling (Scheu and Parkinson, 1994; Tomlin et al., 1995; Bohlen et al., 2004; Suárez et al., 2004; Hale et al., 2005b) but has also affected herbaceous species diversity (Gundale, 2002; Hale, 2006; Holdsworth, 2007).

Habitat typing is just one classification system that both scientists and managers can use to assess and classify forests. The Guide to Forest Communities and Habitat Types of Michigan by Burger and Kotar (2003) was developed along a moisture and soil nutrient gradient. The objectives of the resampling in this study were to monitor changes in summer herbaceous vegetation after 10 years, to gain a better understanding of possible shifts in herbaceous species communities, and to observe the potential impacts exotic earthworms may have on the herbaceous community. We hypothesized that the spring and summer herbaceous community would adhere to similar nutrient and moisture gradients that were observed ten years previously. We 
also hypothesized that herbaceous species composition would differ between years (2000 vs. 2010) and between seasons (spring and summer). We could not identify exact mechanisms that could lead to compositional shifts between years and seasons as these were not measured during the first sampling, but we did hypothesize that: 1) herbaceous species composition may be changing due to high earthworm densities which would lead to simplified plant communities between sample periods; 2) increased percent cover of a few invasive or weedy species may outcompete native species, reducing species richness and diversity; and 3) spring ephermals would decrease and summer herbaceous species would increase in percent cover and frequency as the canopy closed.

\section{Methods}

\section{Study area}

Within the Western Upper Peninsula of Michigan there is approximately two million ha of forested land. Of this, thirty-three percent $(650,000 \mathrm{ha})$ is located within Houghton, Keweenaw, and Ontonagon counties. The vast majority (93\%) of this 650,000 million ha is in young forests, under 100 years (Forest Inventory Data Online, 2010). The three most common cover types are the maple/beech/birch (57\%), aspen/birch (19\%), and spruce/fir (10\%) (Forest Inventory Data Online, 2010). Previous glacial activity greatly influenced the surface geology occurring in these counties; common geological features include ground moraines, end moraines, outwash deposits, and glacial lake shoreline (Soil Conservation Service, 1991, 2006, 2010).

All three counties generally have a continental climate, with average daily maximum temperatures of $-6.7^{\circ} \mathrm{C}$ and $23.8^{\circ} \mathrm{C}$ and average daily minimum temperatures of $13.9^{\circ} \mathrm{C}$ and $12.4^{\circ} \mathrm{C}$ for January and July respectively (recorded in Houghton County; Soil Conservation Service, 1991). Temperatures are generally warmer in the summer and cooler in the winter with increasing distance from Lake Superior. Average precipitation is $0.87 \mathrm{~m}$ with an additional $5.3 \mathrm{~m}$ of average snowfall (Soil Conservation Service, 1991, 2006, 2010). Normal season conditions occurred during the summer sampling of 2000 (personal communication, John Kotar). Abnormal seasonal temperatures and precipitation occurred during the summer of 2010, the year of our resampling. There were only trace snowfall events during the months of March and April; compared to March and April 2000, there was $7.70 \mathrm{~cm}$ and $2.21 \mathrm{~cm}$, respectively, less precipitation in 2010 (PRISM Climate Group, 2004). Maximum temperatures during the months of April and May, 2010 were also $5.21^{\circ} \mathrm{C}$ and $0.79^{\circ} \mathrm{C}$ above maximum temperatures recorded for April and May, 2000.

Six different habitat types were selected for resampling during the spring and summer of 2010 in Houghton, Keweenaw, and Ontonagon counties. The six habitat types span a range of moisture and nutrient richness. General characteristics of each habitat type, along with the full and abbreviated name, can be found in Table 1. 
Table 1. Summary information of habitat types that were resampled in 2010. Habitat types are arranged from least productive to most productive. Additional information on each habitat type can be found in The Guide to Forest Communities and Habitat Types of Michigan by Burger and Kotar, 2003.

\begin{tabular}{|c|c|c|c|c|}
\hline Habitat Type & Acronym & $\begin{array}{l}\text { Common } \\
\text { Overstory Species }\end{array}$ & Soils & $\begin{array}{l}\text { Moisture/ } \\
\text { Nutrient }\end{array}$ \\
\hline $\begin{array}{l}\text { Pinus strobus - Acer rubrum } \\
\text { Vaccinium angustifolium- } \\
\text { Cornus canadensis variant }\end{array}$ & PArV-Co & $\begin{array}{l}\text { Pinus resinosa, Pinus } \\
\text { strobus, Pinus banksiana, } \\
\text { Acer rubrum, Betula } \\
\text { papyrifera }\end{array}$ & $\begin{array}{l}\text { Deep lacustrine } \\
\text { deposits of sand } \\
\& \text { gravel }\end{array}$ & $\begin{array}{l}\text { Dry/poor } \\
\text { nutrient }\end{array}$ \\
\hline $\begin{array}{l}\text { Acer saccharum - Acer rubrum } \\
\text { Aster macrophyllus }\end{array}$ & AArAst & $\begin{array}{l}\text { Acer saccharum, Acer } \\
\text { rubrum, Quercus rubra, } \\
\text { Abies balsamea, Betula } \\
\text { papyrifera }\end{array}$ & $\begin{array}{l}\text { Sand and loamy } \\
\text { sand soils } \\
\text { over bedrock }\end{array}$ & $\begin{array}{l}\text { Dry-mesic/ } \\
\text { poor } \\
\text { to medium } \\
\text { nutrients }\end{array}$ \\
\hline $\begin{array}{l}\text { Acer saccharum-Acer rubrum/ } \\
\text { Lycopodium annotimum }\end{array}$ & AArLy & $\begin{array}{l}\text { Acer saccharum, Acer } \\
\text { rubrum, Betula } \\
\text { alleghaniensis }\end{array}$ & $\begin{array}{l}\text { Loamy sand } \\
\text { to loam } \\
\text { soils over }\end{array}$ & $\begin{array}{l}\text { Dry-mesic/ } \\
\text { poor } \\
\text { to medium } \\
\text { nutrients }\end{array}$ \\
\hline $\begin{array}{l}\text { Acer saccharum- Tsuga } \\
\text { canadensis/ Maianthenum } \\
\text { canadense-Osmorhiza claytoni } \\
\text { variant }\end{array}$ & ATM-O & $\begin{array}{l}\text { Acer saccharum, Acer } \\
\text { rubrum, Tilia americana }\end{array}$ & $\begin{array}{l}\text { Sandy loam soils } \\
\text { with clay } \\
\text { subsurface layers }\end{array}$ & $\begin{array}{l}\text { Mesic/medium } \\
\text { nutrient }\end{array}$ \\
\hline $\begin{array}{l}\text { Acer saccharum- Tsuga } \\
\text { canadensis/ Maianthenum } \\
\text { canadense-Smilacina racemosa } \\
\text { variant }\end{array}$ & ATM-Sm & $\begin{array}{l}\text { Acer saccharum, Acer } \\
\text { rubrum, Tilia americana, } \\
\text { Betula alleghaniensis, Tsuga } \\
\text { canadensis }\end{array}$ & $\begin{array}{l}\text { Loamy sand to } \\
\text { sandy loam soil } \\
\text { with cobbly } \\
\text { subsurfaces }\end{array}$ & $\begin{array}{l}\text { Mesic/medium } \\
\text { nutrient }\end{array}$ \\
\hline $\begin{array}{l}\text { Acer saccharum- Tsuga } \\
\text { canadensis/Dryopteris spinulosa } \\
\text { - Caulophyllum thalictroides } \\
\text { variant }\end{array}$ & ATD-Ca & $\begin{array}{l}\text { Acer saccharum, Tilia } \\
\text { americana, Fraximus } \\
\text { americana, Betula } \\
\text { alleghaniensis, Tsuga } \\
\text { canadensis }\end{array}$ & $\begin{array}{l}\text { Clay deposits with } \\
\text { loamy textured } \\
\text { surfacelayer }\end{array}$ & $\begin{array}{l}\text { Mesic/medium } \\
\text { to rich nutrient }\end{array}$ \\
\hline
\end{tabular}

\section{Vegetation sampling}

Thirty of the 200 plots used to create The Guide to Forest Communities and Habitat Types of Michigan for the Western Upper Peninsula (Burger and Kotar, 2003) were relocated and resampled during the spring and summer of 2010. Original plot locations were not permanently marked during the summer of 2000 but clear directions were recorded for each plot. Plots were relocated in spring 2010 and a GPS location was taken at each plot to document plot location and to relocate plots during the summer sampling period. Three of the thirty plots $(10 \%)$ had to be offset slightly due to extreme changes at the original plot location such as a new trail or building. Even with these offsets and lack of permanent plots, we are confident that the sample locations are representative of the forest communities sampled during the summer of 2000.

Sampling in 2010 was modified slightly from the original sampling during the summer of 2000 (Burger and Kotar, 2003). Sampling in 2010 occurred during the spring (May $4^{\text {th }}-$ May $24^{\text {th }}$ ) before full leaf on and in summer (June $24^{\text {th }}-$ July $13^{\text {th }}$ ). Summer sampling coincided with phenological changes in plants, such as the ripening of Vaccinium spp. and Rubus spp. berries.

At each plot location, a $21 \mathrm{~m} \times 14 \mathrm{~m}$ macroplot was established (Burger and Kotar, 2003). Modification of the original sampling included the use of $1-\mathrm{m}^{2}$ plots to measure herbaceous species (Fig. 1). Environmental data such as topography, configuration, slope, and time since last harvest activity were recorded. Topography was described as a ridge, upper slope, mid slope, lower slope, or bench. Configuration was described as 
convex, straight, concave, or undulating. Slope was categorized into four classes: 1) 0$10 \%, 2) 11-25 \%, 3) 26-50 \%$, and 4) $51 \%$ and greater. Harvest activity was identified by the presence of stumps and small diameter harvest slash and was estimated as having occurred within the last five years, six to ten years ago, eleven to fifteen years ago, sixteen to twenty years ago, and greater than twenty one years.

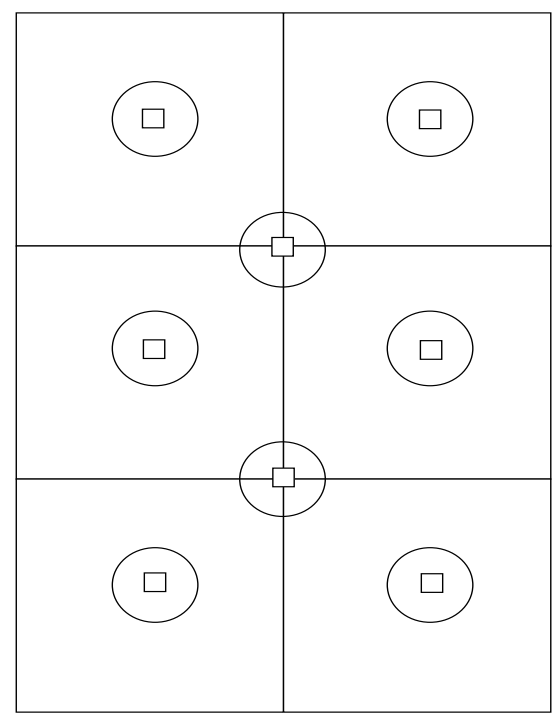

Figure 1. Sampling design used during the spring and summer of 2010 was slightly modified from Burger and Kotar (2003). Within the $21 \mathrm{~m}$ by $14 \mathrm{~m}$ macroplot, eight $1-\mathrm{m}^{2}$ square quadrats were established to measure herbaceous species. Eight circular 0.0004-ha plots were used to measure seedlings and saplings.

Inside each macroplot, all overstory species greater than $10 \mathrm{~cm}$ dbh were identified to species, and diameter was measured at breast height $(1.37 \mathrm{~m})$. Overstory trees were divided into five canopy classes: open grown, dominant, co-dominant, intermediate, or suppressed (Oliver and Larson, 1996). Diameter at breast height was also measured on all snags. Overstory measurements were conducted last to decrease trampling of the herbaceous layer.

Within the macroplot, eight $1-\mathrm{m}^{2}$ quadrats were used to sample herbaceous species (Fig. 1). All herbaceous species within the quadrat were identified to species with the exception of grasses, sedges, mosses, and certain families where identification could only be made to genus. After identification, species were placed into a coverage class. The same coverage classes were used as the original sampling in 2000: 1) 0-1\%,2) 1$5 \%, 3) 5-10 \%$, 4) $10-25 \%, 5) 25-50 \%$, 6) $50-75 \%$, and 7) greater than $75 \%$. All estimates of percent cover in 2010 were done by one researcher to minimize bias. Using the quadrat locations, two opposite corners were selected to estimate canopy cover using a spherical concave densitometer for a total of 16 measurements per macroplot. The macroplot was then searched for any new herbaceous species that were not present in any quadrat; these species were recorded as present.

At the center of each of the eight quadrats, a 0.0004-ha circular plot was established to measure the seedling and sapling layers. Seedlings were defined as any woody tree species less than $30.5 \mathrm{~cm}$ in height. Saplings were subdivided into small saplings (30.6 $\mathrm{cm}$ to $1.4 \mathrm{~m}$ in height) and large saplings (1.5 $\mathrm{m}$ in height to $9.9 \mathrm{~cm}$ in diameter). 
Density and percent cover were measured for seedlings, small saplings, and large saplings by species. Percent cover was estimated using the same coverage classes used for the herbaceous species.

\section{Earthworm sampling}

Three $0.5-\mathrm{m}^{2}$ metal quadrats were placed randomly within the macroplot to sample earthworm populations by liquid extraction during the first two weeks of September (Sept $2-12,2010)$ to ensure that leaf litter sampled was from the previous fall. The quadrats were placed into the soil to ensure that the extraction solution would not leak outside the sample area; leaf litter depth was measured to one-tenth of a centimeter and classified based on the major overstory species present. The leaf litter was then collected.

The liquid extraction solution consisted of $40 \mathrm{~g}$ ground yellow mustard mixed in 3.8 L of water. This solution has been shown to be a skin irritant and causes earthworms to surface (Hale, 2007). After the solution was poured, we collected earthworms for 3 minutes (no additional earthworms were found after 3 minutes). Earthworms were collected and later identified in the lab.

In the lab, the wet weight of the leaf litter samples were measured after each sampling day and then placed in a drying oven at $30^{\circ} \mathrm{C}$ for a minimum of seven days. Oven dried samples were then weighed to the nearest tenth of a gram.

Collected earthworms were identified within 48 hours. Due to the high amount of juveniles present, earthworms were only identified to genus with three genera collected throughout the sample location: Aporrectodea spp., Dendrodilus spp., and Lumbricus spp. All earthworms were measured to the nearest millimeter for their total length. For each macroplot, total earthworm biomass (ash-free dry mass) was determined for all earthworm species combined and each genus (Hale et al., 2004).

\section{Data analysis}

Herbaceous species were divided into different growth forms based on the USDA PLANTS Database (2011): 1) equisetum, 2) fern, 3) forb/herb, 4) graminoids, 5) lichen, 6) moss, 7) shrub, 8) sub-shrub, and 9) vine. Species were also classified as native or invasive using information about invasive species from the USDA PLANTS Database (2011). The definition used for invasive species was from Executive Order 13112, Appendix 1 (1999) where an invasive species is defined as "non-native (or alien) to the ecosystem under consideration and whose introduction causes or is likely to cause economic or environmental harm or harm to human health." Weedy plants were classified as invasive due to the potential decrease diversity. Species shade tolerance was also classified using the USDA PLANTS Database. When tolerance was not listed, the description of the habitat that the species was normally found in was used (Voss, 1985; Newcomb, 1989; Voss, 1996). Herbaceous species with habitat descriptions of woodlands or woods were classified as tolerant; open woods and thickets were classified as midtolerants; and waste places, roadsides, and meadows were classified as intolerant.

Data was summarized two ways due to slight differences in sampling methods between 2000 and 2010. Herbaceous species richness was summarized at the macroplot level between years and between seasons. Diversity and evenness could not be compared between years in the understory layer due to differences in area sampled. Overstory species were summarized by trees per hectare and basal area per hectare. 
Comparison of overstory basal area between summer 2000 and 2010 required overstory trees to be placed into $5.1 \mathrm{~cm}$ diameter classes with all trees greater than $55.6 \mathrm{~cm}$ in diameter (dbh) excluded to be consistent with the original data collection. Therefore, all overstory basal area measurements are underestimates as there is no way to calculate basal area of trees with unknown diameters above $55.6 \mathrm{~cm}$. Diameter to the nearest tenth of a centimeter was used to calculate overstory basal area when comparing spring and summer data collected in 2010.

Trees per hectare within the macroplot was used to calculate overstory species richness. Trees per hectare was also used to calculate Shannon's Index of Diversity (Maguurran, 1988),

$$
\mathrm{H}=-\sum \mathrm{p}_{\mathrm{i}} / \mathrm{p}_{\mathrm{t}} * \ln \left(\mathrm{p}_{\mathrm{i}} / \mathrm{p}_{\mathrm{t}}\right)
$$

where $\mathrm{H}$ is Shannon's Index of Diversity, $\mathrm{p}_{\mathrm{i}}$ is the cover of species $\mathrm{i}$, and $\mathrm{p}_{\mathrm{t}}$ is the total species richness for all species in the plot.

Evenness was also calculated using trees per hectare (Margurran, 1988)

$$
\mathrm{EH}=\mathrm{H} / \mathrm{Hmax} \quad \mathrm{Hmax}=\mathrm{H} / \mathrm{lnS}
$$

where $E_{H}$ is evenness, $H_{\max }$ is the maximum potential evenness, and $\ln S$ is the natural $\log$ of species richness.

Shannon's index of diversity and evenness for herbaceous species sampled in spring and summer of 2010 were summarized by averaging the percent cover of the eight $1-\mathrm{m}^{2}$ quadrats in each plot.

Repeated measures ANOVA in statistical interface R ( $\mathrm{R}$ Development Core Team, 2011) was used to test for significant differences between habitat types and between either years or seasons. Tukey's Honest Significant Difference (Tukey, 953) was used when there were significant differences between years (2000 vs. 2010), seasons (spring vs. summer), and habitat types (see Table 1). Linear regression was used to explore relationships between exotic earthworms and percent cover of vegetation and environmental variables.

Nonmetric multidimensional scaling (NMS) ordination using PC-ORD Version 5 (McCune and Mefford, 2011) was used to compare the shift in the herbaceous layer between sampling periods and between habitat types. NMS has relaxed normality assumptions and does not assume a linear response to different gradients which is common in ecological data (McCune and Grace, 2002). Herbaceous species presence/absence data at the macroplot level was used to run the ordination. NMS was run on herbaceous species presence/absence data for summer 2000 versus summer 2010 and spring 2010 versus summer 2010. Autopilot mode (slow and thorough) was selected using Sørensen (Bray-Curtis) distance measurement and a random starting point for both datasets. Two hundred and fifty runs were completed for both the real data and randomized data to determine dimensionality for both data sets. Correlation analysis in statistical interface R (R Development Core Team, 2011) was used to test environmental variables used in the ordinations for significance. 


\section{Results}

\section{Herbaceous species composition}

During the summer of 2000, 80 herbaceous species were identified across all habitat types with only four species (5\% of all species) considered invasive. A total of 130 herbaceous species were sampled during both spring and summer of 2010 across all habitat types with 25 species (19\% of all species) considered invasive. There were 69 new species observed in 2010 with 22 or $33 \%$ of these new species considered invasive. Seventeen species were only observed in 2000; none were considered invasive. A complete list of herbaceous species can be found in Appendix A (Table A.1).

A greater number of species, 114, were sampled during the summer 2010 period compared with 90 species sampled during spring 2010 across all habitat types. Sixteen herbaceous species were captured in the spring sampling period which would have been missed with only summer sampling. Habitat types are delineated on the basis of floristic differences. However, few species were unique to only one habitat type; herbaceous species overlap between habitat types ranged from 11-57\%. Habitat types occur across range of nutrient and moisture conditions (Table 1). PArV-Co and ATD-Ca represent the least and most productive habitat types, respectively. These two habitat types, PArV-Co and ATD-Ca contained the fewest species in common (11\%) in summer 2010. However, habitat types with more similar moisture and nutrient conditions shared more species in common with AArAst and AArLy sharing over half (57\%) of the same species. Species such as Dryopteris spinulosa, Maianthemum canadense, Maianthemum racemosoum ssp. racemosum, Polygonatum pubescens, and Trientalis borealis exhibited a high frequency of occurrence within habitat types and between habitat types in both the summer 2000 and spring and summer 2010 sampling periods.

\section{Comparison between summer 2000 and 2010}

Overstory trees per hectare significantly decreased from 2000 to 2010 ( $\mathrm{p}<0.001$ ); there was an average $31 \%$ decrease between all habitat types, with no significant difference between habitat types (Table 2). A similar trend was observed with overstory basal area per hectare $(\mathrm{p}<0.001)($ Table 2$)$ with a significant difference between habitat types; PArV-Co had greater basal area per hectare than AArAst $(\mathrm{p}=0.03)$ and AArLy $(p=0.03)$. All habitat types had at least one plot that was surmised through the identification of recent stumps to have had management activities within the past 10 years. Habitat types ATM-Sm and AArLy had the greatest number of plots (three and two respectively) with management activity occurring in the last five years, while also experiencing the greatest decrease in overstory basal area (47\% and $48 \%$ respectively).

Total herbaceous species richness significantly increased between years $(p<0.001)$ with significant differences between habitat types $(\mathrm{p}<0.001$; Table 2$)$. Native herbaceous species richness did not vary between years but was significantly different between habitat types $(\mathrm{p}<0.001 ;$ Fig. 2). The most productive habitat type, ATD-Ca, had greater total herbaceous species richness and native herbaceous species richness than all other habitat types except ATM-O (Table 2). Invasive herbaceous species richness increased between years $(\mathrm{p}<0.001)$ but there was no significant difference between habitat types (Fig. 2). 
Table 2. Response of overstory structure and herbaceous species richness to year of sampling, habitat type, and their interaction. All variables are summarized at the macroplot level The associated standard errors are in parentheses.

\begin{tabular}{|c|c|c|c|c|c|c|c|c|c|}
\hline & \multirow{2}{*}{$\begin{array}{l}\text { Habitat } \\
\text { Types }\end{array}$} & \multirow{2}{*}{$\begin{array}{l}\text { Summer } \\
2000\end{array}$} & \multirow{2}{*}{$\begin{array}{l}\text { Summer } \\
2010\end{array}$} & \multicolumn{2}{|r|}{ Year } & \multicolumn{2}{|c|}{ Habitat Type } & \multicolumn{2}{|c|}{ Interaction } \\
\hline & & & & $\mathrm{F}_{1,48}$ & p-value & $\mathrm{F}_{5,48}$ & p-value & $\mathrm{F}_{5,48}$ & p-value \\
\hline \multirow{6}{*}{$\begin{array}{l}\text { Trees Per } \\
\text { Hectare }\end{array}$} & PArV-Co & 945 (39) & $898(176)$ & 4.67 & $<0.001$ & 0.83 & 0.53 & 1.22 & 0.31 \\
\hline & AArAst & $1007(66)$ & $660(128)$ & & & & & & \\
\hline & AArLy & $1034(140)$ & $537(46)$ & & & & & & \\
\hline & ATM-Sm & $959(113)$ & $510(108)$ & & & & & & \\
\hline & ATM-O & $980(129)$ & $694(110)$ & & & & & & \\
\hline & ATD-Ca & $850(63)$ & $653(54)$ & & & & & & \\
\hline \multirow{6}{*}{$\begin{array}{l}\text { Basal Area } \\
\text { Per Hectare } \\
\left(\mathrm{m}^{2} \mathrm{ha}^{-1}\right)\end{array}$} & PArV-Co & $50(3)$ & $36(5)$ & 35.20 & $<0.001$ & 3.25 & 0.01 & 0.52 & 0.76 \\
\hline & AArAst & $42(5)$ & $24(7)$ & & & & & & \\
\hline & AArLy & $38(4)$ & $20(3)$ & & & & & & \\
\hline & ATM-Sm & $39(5)$ & $19(3)$ & & & & & & \\
\hline & ATM-O & $40(5)$ & $25(4)$ & & & & & & \\
\hline & ATD-Ca & $31(2)$ & $24(4)$ & & & & & & \\
\hline \multirow{6}{*}{$\begin{array}{l}\text { Total } \\
\text { Herbaceous } \\
\text { Species } \\
\text { Richness }\end{array}$} & PArV-Co & $17.4(0.8)$ & $15.4(2.4)$ & 7.69 & 0.007 & 7.01 & $<0.001$ & 2.24 & 0.07 \\
\hline & AArAst & $15.8(2.4)$ & $16.0(2.5)$ & & & & & & \\
\hline & AArLy & $14.8(1.8)$ & $18.0(2.0)$ & & & & & & \\
\hline & ATM-Sm & $11.8(1.1)$ & $21.0(1.3)$ & & & & & & \\
\hline & ATM-O & $17.2(0.4)$ & $24.0(2.2)$ & & & & & & \\
\hline & ATD-Ca & $24.4(2.2)$ & $26.0(3.0)$ & & & & & & \\
\hline
\end{tabular}

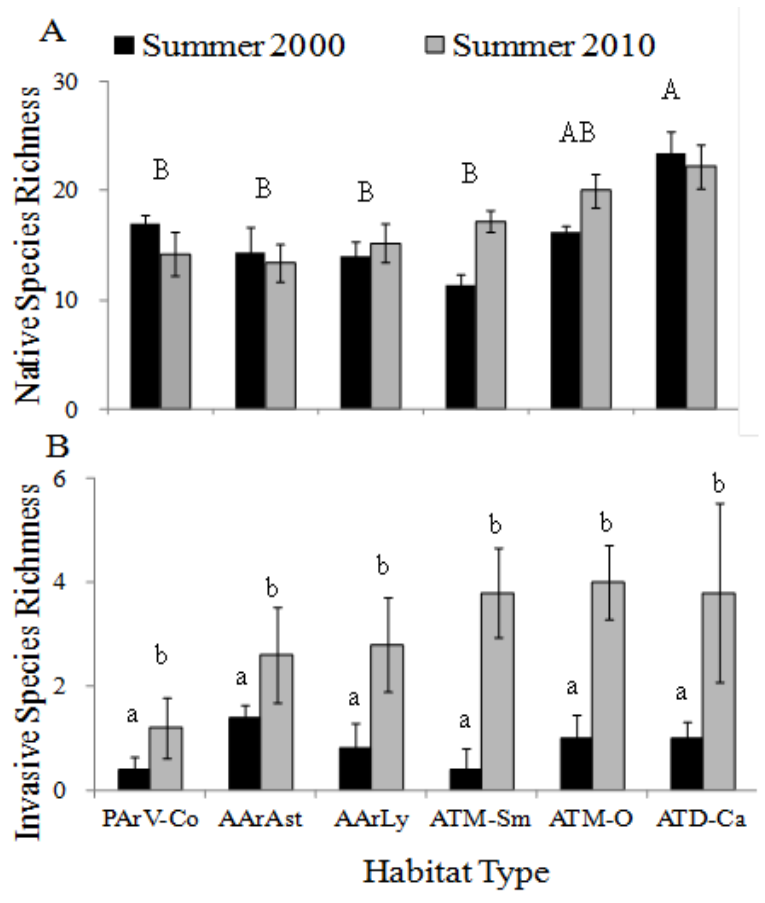

Figure 2: Native (A) and Invasive (B) herbaceous species richness observed at the macroplot level in summer 2000 and 2010. Upper case letters that are different represent significant differences between habitat types at $\alpha=0.05$. There were no significant differences observed

between years for native herbaceous species richness. Lower case letters represent a significant difference between years at $\alpha=0.05$. There were no significant differences between years across habitat types for invasive species richness. 


\section{Comparison between spring and summer 2010}

Canopy cover increased from spring 2010 to summer $2010(\mathrm{p}<0.001)$ but did not differ significantly between habitat types (Table 3 ). Herbaceous species percent cover, richness, and evenness all increased significantly from spring to summer $(\mathrm{p}<0.001 ; \mathrm{p}=0.01$; $\mathrm{p}<0.001)$ (Table 3). The two least productive habitat types, PArV-Co and AArAst, had significantly lower herbaceous species richness than the three richest habitat types, ATMSm $(\mathrm{p}=0.006, \mathrm{p}=0.02)$, ATM-O $(\mathrm{p}<0.001, \mathrm{p}=0.03)$, and ATD-Ca $(\mathrm{p}=0.005, \mathrm{p}=0.02)$ (Fig. 3). There were significantly greater diversity, using Shannon's Index of Diversity, in ATM-Sm than AArAst $(\mathrm{p}=0.03)$ and ATM-O and ATD-Ca than AArAst $(\mathrm{p}=0.07$; $\mathrm{p}=0.04)$; herbaceous evenness was significantly greater in ATM-Sm than AArAst ( $\mathrm{p}=0.02)$ (Fig. 3).
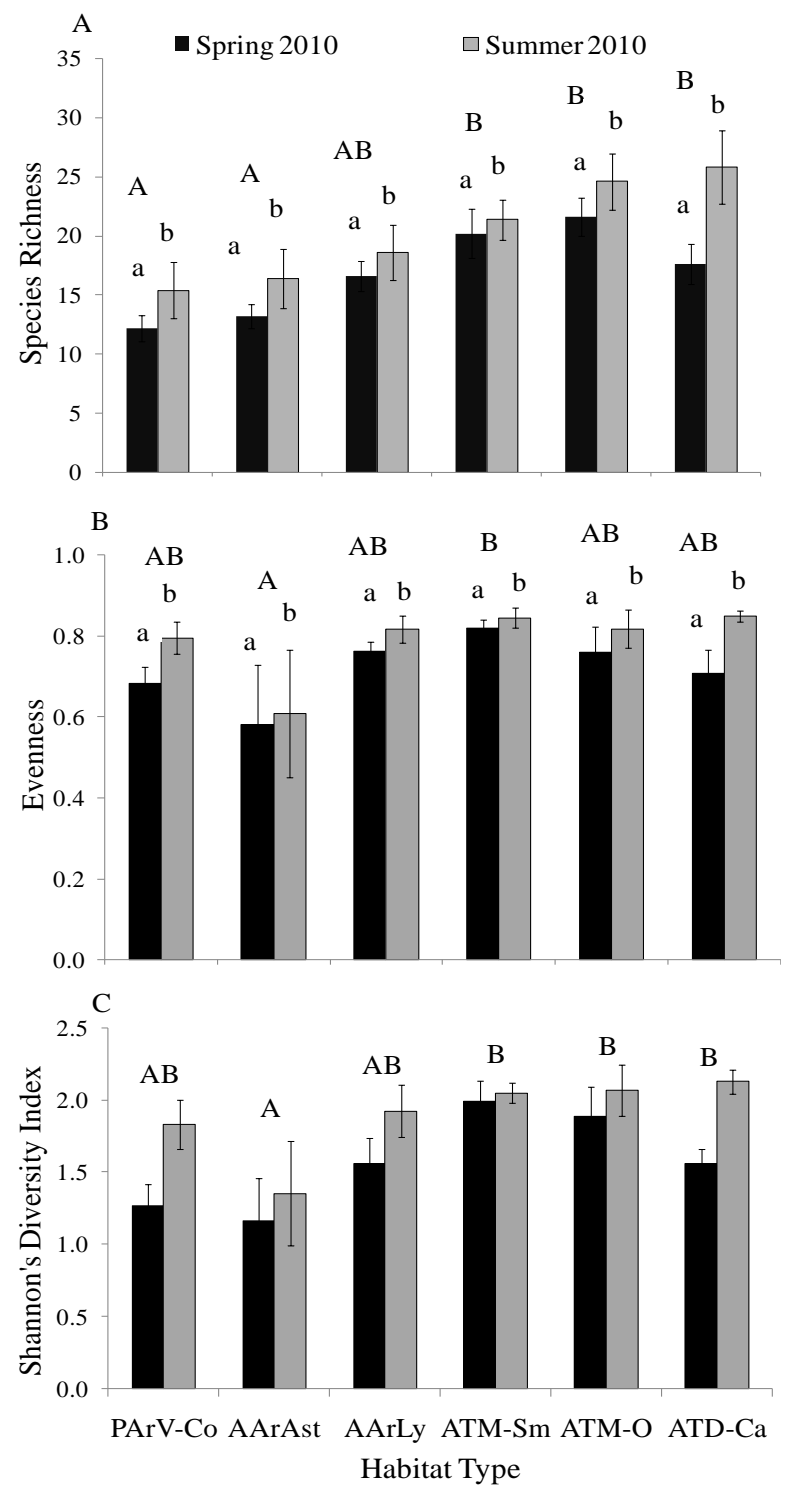

Figure 3: Herbaceous Species Richness (A), Evenness (B), and Shannon's Diversity (C) for spring and summer 2010. Species richness was observed at the macroplot level. Herbaceous evenness and Shannon's diversity were calculated from $1-\mathrm{m}^{2}$ plots. Upper case letters that are different represent a significant difference between habitat types at $\alpha=0.05$. Lower case letters that are different represent a significant difference between seasons at $\alpha=0.05$. There was no significant difference between years for Shannon's Diversity. 
Table 3. Response of the canopy and herbaceous species percent cover to season, habitat type and their interaction. Herbaceous species percent cover was summarized at the subplot level (eight 1-m2 quadrats). The associated standard errors are in parentheses.

\begin{tabular}{|c|c|c|c|c|c|c|c|c|c|}
\hline & \multirow{2}{*}{$\begin{array}{l}\text { Habitat } \\
\text { Types }\end{array}$} & \multirow{2}{*}{$\begin{array}{l}\text { Spring } \\
2010\end{array}$} & \multirow{2}{*}{$\begin{array}{l}\text { Summer } \\
2010\end{array}$} & \multicolumn{2}{|c|}{ Season } & \multicolumn{2}{|c|}{ Habitat Type } & \multicolumn{2}{|c|}{ Interaction } \\
\hline & & & & $\mathrm{F}_{1,48}$ & p-value & $F_{5,48}$ & p-value & $F_{5,48}$ & p-value \\
\hline \multirow{6}{*}{$\begin{array}{l}\text { Percent Canopy } \\
\text { Closure }\end{array}$} & PArV-Co & $86(0.7)$ & $90(0.9)$ & 45.77 & $<0.001$ & 0.71 & 0.62 & 1.19 & 0.33 \\
\hline & AArAst & $73(0.8)$ & $92(1.2)$ & & & & & & \\
\hline & AArLy & $78(1.0)$ & $93(0.5)$ & & & & & & \\
\hline & ATM-Sm & $81(0.6)$ & $92(0.8)$ & & & & & & \\
\hline & ATM-O & $79(1.0)$ & $93(0.5)$ & & & & & & \\
\hline & ATD-Ca & $80(1.0)$ & $91(0.7)$ & & & & & & \\
\hline \multirow{6}{*}{$\begin{array}{l}\text { Herbaceous } \\
\text { Species } \\
\text { Percent Cover }\end{array}$} & PArV-Co & $25(11)$ & $61(27)$ & 21.06 & $<0.001$ & 2.38 & 0.052 & 0.40 & 0.84 \\
\hline & AArAst & $16(7)$ & $40(18)$ & & & & & & \\
\hline & AArLy & $25(11)$ & $55(25)$ & & & & & & \\
\hline & ATM-Sm & $28(12)$ & $73(33)$ & & & & & & \\
\hline & ATM-O & $33(15)$ & $66(30)$ & & & & & & \\
\hline & ATD-Ca & $38(17)$ & $67(30)$ & & & & & & \\
\hline
\end{tabular}

\section{Herbaceous composition shifts}

A three-dimensional solution was found through NMS with a final stress of 16.9 in the comparison between summer 2000 and 2010. The ordination explained $83 \%$ of the variation in the data; axis 1 and axis 2 explained the most variation, $18 \%$ and $67 \%$ respectively (Fig. 4).

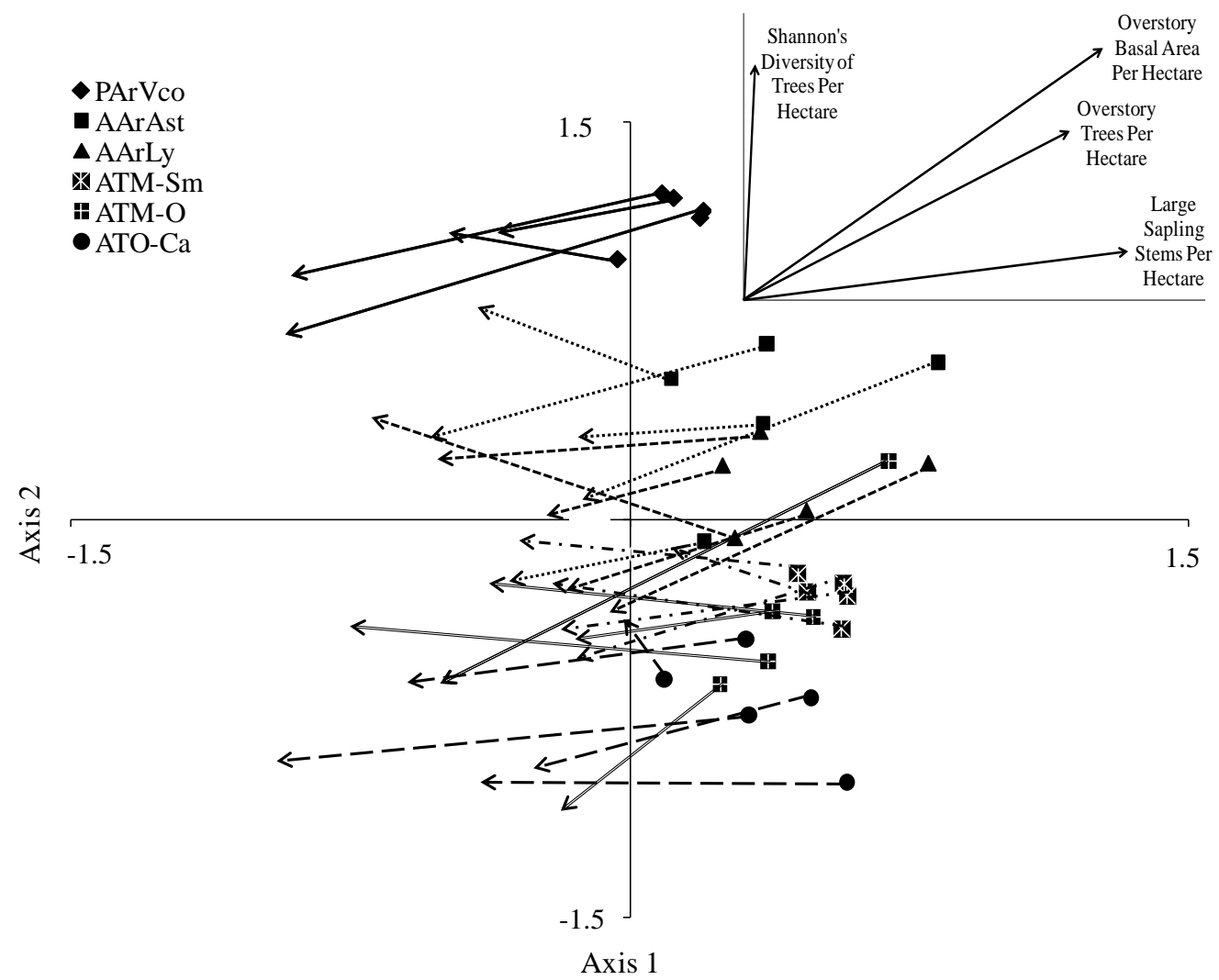

Figure 4. Non-metric multi-dimensional scaling ordination of herbaceous species communities for six habitat types in the western Upper Peninsula for summer 2000 and summer 2010. Axis 1 
explains $18 \%$ percent of the variation while Axis 2 explains $67 \%$ of the variation. Habitat type are displayed in order of productivity; PArV-Co the least productive to ATO-Ca the most productive. Markers represent summer 2000 conditions and arrows represent direction and magnitude of composition change. Where the arrows end represent summer 2010 herbaceous community composition. Longer arrows represent greater difference between years. The insert is the significant environmental variables $(p=0.05)$ and their relation to ordination space.

Overstory TPH and basal area per hectare were both strongly associated with axis 1 and axis 2 (Fig. 4). Overstory Shannon's diversity calculated with TPH was strongly associated with axis 2; large sapling density was strongly associated with axis 1 (Fig. 4). There was generally strong and consistent movement in all habitat types to areas of decreased overstory TPH and basal area per hectare (Fig. 4). However, even with increasing invasive species and changes in overstory density, the productivity gradient between habitat types was still evident.

A three-dimensional solution with a final stress of 17.5 was also found in the comparison between spring and summer 2010. The ordination explained $77 \%$ of the variation in the data; axis 1 and axis 3 explained the most variation, 54\% and 14\% respectively (Fig. 5). Percent canopy cover is the main driving variable in this ordination and is strongly associated with axis 3 (Fig. 5). Species shifted from a more open canopy in the spring to a closed canopy in the summer. Percent down dead wood and seedling richness were associated with axis 3 , while overstory TPH and basal area per hectare were associated with axis 1 (Fig. 5).

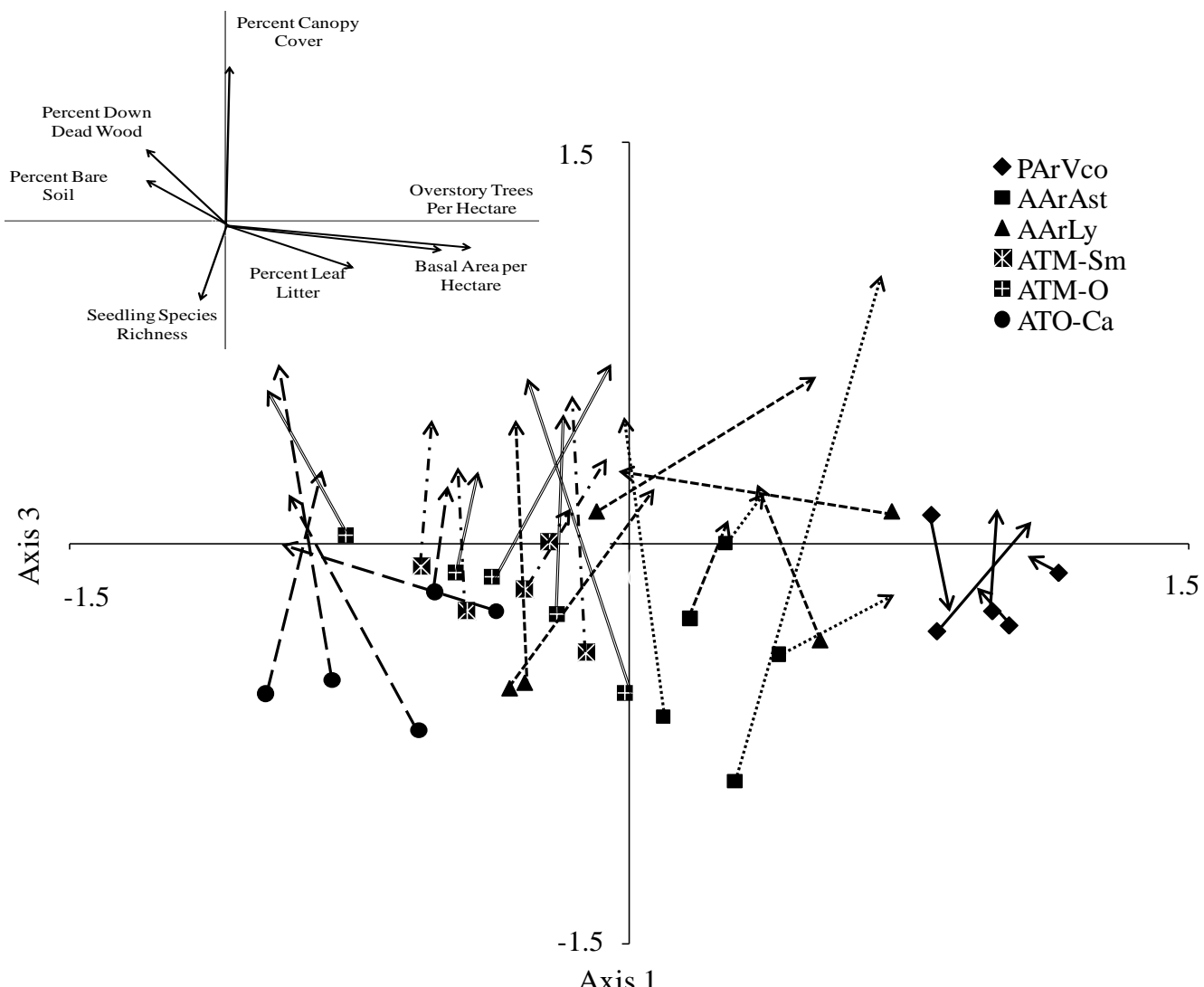

Figure 5. Non-metric multi-dimensional scaling ordination of herbaceous species communities for six habitat types in the western Upper Peninsula for spring and summer 2010. Axis 1 
explains $54 \%$ percent of the variation while Axis 3 explains $14 \%$ of the variation. Habitat type are arranged in order of productivity; PArV-Co the least productive to ATO-Ca the most productive. Markers represent spring 2010 conditions and arrows represent direction and magnitude of composition change. Where the arrows ends represent summer 2010 herbaceous community composition. Longer arrows represent greater difference between spring and summer. The insert is the significant environmental variables $(p=0.05)$ and their relation to ordination space.

\section{Earthworm densities}

Overall earthworm ash-free dry mass generally increased from less productive habitat types to more productive habitat types, with Lumbricus spp. generally following the same trends (Fig. 6). The PArV-Co and AArLy habitat types had significantly lower ash-free dry mass than ATD-Ca ( $\mathrm{p}=0.01 ; \mathrm{p}=0.03)$ (Fig. 6). There were significant negative relationships between ash-dry weight of Lumbricus spp. and both spring and summer herbaceous species percent cover $\left(p=0.010, r^{2}=0.21 ; p=0.019\right.$, $\left.\mathrm{r}^{2}=0.18\right)$. Total ash-dry weight of all earthworms followed this same trend $(\mathrm{p}=0.049$, $\mathrm{r}^{2}=0.24 ; \mathrm{p}=0.005, \mathrm{r}^{2}=0.13$ ). There was a significant negative relationship between ashdry weight of Dendrobaena spp. and total herbaceous species richness, native species richness, and invasive species richness $\left(\mathrm{p}=0.003, \mathrm{r}^{2}=0.27 ; \mathrm{p}=0.031, \mathrm{r}^{2}=0.15 ; \mathrm{p}=0.006\right.$, $r^{2}=0.23$ ), respectively.

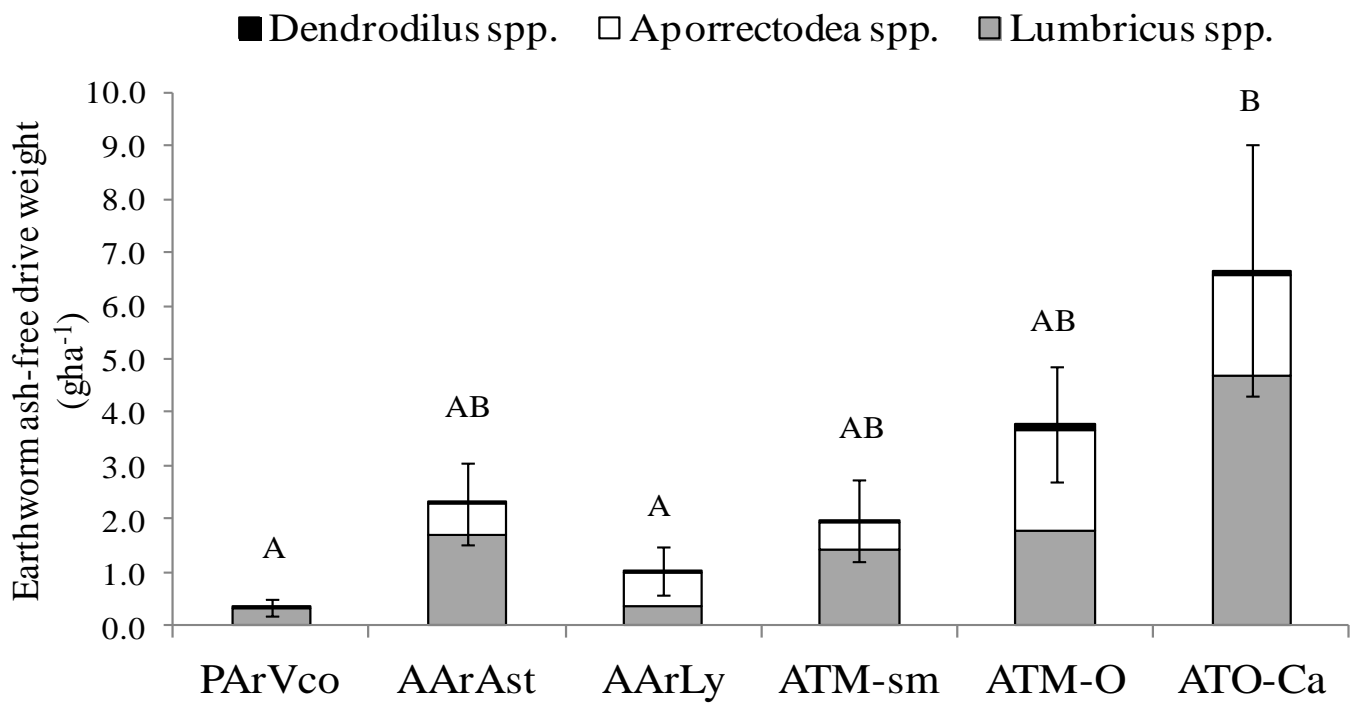

Figure 6. Earthworm ash-free dry weight ( $g$ ha'l) by genus for each habitat type. Letters that are different represent a significant $(\alpha=0.05)$ difference between habitat types comparing total ash-free dry weight of earthworms, not by individual species.

\section{Discussion}

Even with changes in herbaceous species composition, overstory density, and canopy cover between years (2000 vs 2010) and between season (spring vs summer) there was still an identifiable productivity gradient between different habitat types (Fig. 4 - 5). Overstory density significantly decreased between 2000 and 2010, which we hypothesize is a result of forest management as all habitat types contained at least one plot where recent stumps and logging slash were observed. It is not known the exact intensity of past harvest activities or the season in which the harvests took place. Forest 
management has been shown to have a variety of effects on the herbaceous layer in a variety of forest types (Metzger and Schultz, 1981; Gilliam et al., 1995; Roberts and Gilliam, 1995; Fredericksen et al., 1999; Jenkins and Parker, 1999; Crow et al., 2002; Scheller and Mladenoff, 2002; Gilliam and Roberts, 2003; Zenner et al., 2006; Kern et al., 2006; Wolf, 2008; and others).

The Argonne Experimental Forest in northern Wisconsin observed no difference in the spring or summer herbaceous communities in even, uneven-aged, or unmanaged stands after 40 years of consistent treatment (Kern et al., 2006). However, at the Ford Forest (Michigan Technological University) differences in summer herbaceous community composition were observed between different harvest intensities after 50 years of management. After a recent harvest, the diameter-limit treatments generally had herbaceous communities with more weedy and invasive herbaceous species (Campione et al., 2012). Scheller and Mladenoff (2002) also observed this increase in early successional and weedy species in uneven-aged northern hardwood stands compared to even-aged or unmanaged stands.

The seasonality of logging can also affect herbaceous species composition. A study in the Chequamegon-Nicolet National Forest observed that herbaceous species that are more vulnerable to disturbance were observed more often in winter-logged sites than summer-logged sites (Wolf et al., 2008). Logging intensity and seasonality may be two unknown variables contributing to increases in invasive species richness between years in this and other studies (Wiegmann and Waller, 2000; Watkins et al., 2003).

Another group of invasive species, European earthworms, may also be having an effect on the herbaceous species composition. Exotic earthworm densities and ash-dry mass were estimated for each habitat type in the present study. There was a general increasing trend between total earthworm ash-free biomass and habitat type productivity. There is no way to estimate exactly how long earthworm populations have been present at each site. All habitat types except for PArV-Co (the habitat type with lowest productivity) had all three genera of earthworms. No earthworms from the Aporrectodea genus were collected during sampling at PArV-Co sites. Aporrectodea species are classified as endogeic, living in soil down to depths of $50 \mathrm{~cm}$, and feed on mineral soil (Hale, 2007). Hale and others (2006) observed that Aporrectodea species were generally behind the leading edge of the earthworm invasion front. The lack of observed Aporrectodea species at the PArV-Co sites during sampling may be a result of their population size being too small to pick up in our sampling. Alternatively, the sandy soils and pine leaf litter of this habitat type may inhibit this genus of earthworms from establishing or creating large populations. The other two genera observed, Dendrobaena and Lumbricus, can be classified as epigeic and anecic or epi-endogeic respectively (Hale, 2007). The genus Dendrobaena is commonly the first earthworm genus to colonize new locations (Hale, 2007).

Our results of a negative relationship between total earthworm ash-free biomass and percent cover of herbaceous species are consistent with Hale and colleagues (2005). However, our results are different than Holdsworth (2007) in that plant species richness increased with increasing mass of the earthworm genera Dendrobaena and Aporrectodea. We observed decreases in total herbaceous species richness, native species richness, and invasive species richness with increasing mass of Dendrobaena $\left(\mathrm{p}=0.003, \mathrm{r}^{2}=0.27 ; \mathrm{p}=0.031, \mathrm{r}^{2}=0.15 ; \mathrm{p}=0.006, \mathrm{r}^{2}=0.23\right)$, respectively. Invasive species richness also decreased with increasing mass of Aporrectodea. These differences may be due to the low total earthworm and individual species biomass that was observed. 
The habitat type ATD-Ca had the highest mass of Aporrectodea which averaged 1.1 $\mathrm{g} / \mathrm{m}^{2}$ compared to an average of $4.8 \mathrm{~g} / \mathrm{m}^{2}$ observed in northern Wisconsin and $3.9 \mathrm{~g} / \mathrm{m}^{2}$ in northern Minnesota (Holdsworth et al., 2007).

These low earthworm populations may be one of the reasons we did not observe the same changes in species richness as other authors (e.g. Gundale, 2002; Hale, 2006; Holdsworth, 2007; Powers and Nagel, 2008). Both earthworm densities and herbaceous species richness generally but not significantly increased with increasing nutrient richness and moisture. We also did not observe simplified herbaceous communities dominated by Carex pensylvanica (Holdsworth et al., 2007; Powers and Nagel, 2008) which does grow in this area but at much lower abundance than in these other studies. Future climate conditions have the possibility to not only affect the current dynamics in forests but also the dynamics of invasive species (e.g. Walther et al., 2002).

These changing climatic conditions have already been observed in the Upper Peninsula of Michigan. Myers and colleagues (2009) observed an increase of approximately $2.1^{\circ} \mathrm{C}$ in the daily minimum and $0.42^{\circ} \mathrm{C}$ in the daily maximum temperatures from 1970 to 2007. Spring ephermals may be more sensitive to these changing conditions since flowering times are closely related to mean monthly temperatures (Miller-Rushing and Primack, 2008). These early flowering plants are an important functional component of ecosystems, reducing nutrient losses from soils (Muller and Bormann, 1976). However, spring ephermals may be more sensitive to repeated disturbances such as uneven-aged management (Metzger and Schultz, 1981; Scheller and Mladenoff, 2002) or may show no difference between managed and unmanaged forests (Kern et al., 2006). We observed a distinct shift in vegetation from spring to summer sampling. As canopy closure occurred at the end of spring/beginning of summer, the herbaceous community shifted from one dominated by spring ephemerals like Claytonia virginica and Erythronium americanum to a herbaceous community dominated by Dryopteris spinulosa, Maianthemum canadense, and Trientalis borealis. Increasing temperatures, especially daily minimum temperatures, may change the relationship spring ephermals have with overstory tree species. Spring ephermals may be important species to monitor and use as early detectors of changing conditions in forest ecosystems. Continual monitoring within these forest communities will allow scientists and managers to observe how a management activity, changing climate, and invasive plants and earthworms interact and influence forest composition.

Acknowledgements. We would like to thank Tim Burger from Terra Silva Forestry Consultants for supplying the 2000 sampling data, and Christopher Webster for statistical assistance. Funding was provided from the Ecosystem Science Center and the School of Forest Resources and Environmental Science at Michigan Technological University.

\section{REFERENCES}

[1] Bohlen, P.J., Groffman, P.M., Fahey, T.J., Fisk, M.C., Suárez, E., Pelletier, D.M., Fahey, F.T. (2004):. Ecosystem consequences of exotive earthwarm invasion of north temperate forests. - Ecosystems 7: 1-12.

[2] Bohlen, P.J., Pelletier, D.M., Groffman, P.M., Fahey, T.J., Fisk, M.C. (2004) Influence of earthworm invasion on redistribution and retention of soil carbon and nitrogen in north temperate forest - Ecosystems 7: 13-27.

[3] Burger, T.L., Kotar, J. (2003): A Guide to Forest Communities and Habitat Types of 
Michigan. - University of Wisconsin-Madison Press. Madison, WI, USA.

[4] Campione, M.A., Nagel, L.M., Webster, C.R. (2012): Herbaceous-layer community dynamics along a harvest-intensity gradient after 50 years of consistent management. Open Journal of Forestry 2: 97-109.

[5] Cayan, D.R., Kammerdiener, S.A., Dettinger, M.D., Caprio, J.M., Peterson, D.H. (2001): Changes in the onset of spring in the western United States. - Bulletin of the American Meteorological Society 84: 399-415.

[6] Clements, F.E. (1936): Nature and structure of the climax. - The Journal of Ecology 24: 252-284.

[7] Clements, F.E. (1916): An analysis of the development of vegetation. - Carnegie Institute Publishing, Washington, D.C., USA.

[8] Coffman, M.S., Alyanak, E.A., Kotar, J., Ferris, J.E. (1983): Field guide habitat type classification system for Upper Peninsula of Michigan and Northeast Wisconsin. - School of Forestry and Wood Products, Michigan Technological University, MI, USA.

[9] Cook, J.E. (1996): Implications of Modern Successional Theory for Habitat Typing: A Review. - Forest Science 42: 67-75.

[10] Crow, T.R., Buckley, D.S., Nauertz, E.A., Zasada, J.C. (2002): Effects of management on the composition and structure of northern hardwood forests in upper Michigan, USA. Forest Science 48: 129-145.

[11] Daubenmire, R. (1976): The use of vegetation assessing the productivity of forest land. Botanical Review 42: 115-141.

[12] Daubenmire, R., Daubenmire B. (1968): Plant Communities: A Text of Plant Synecology. - Harper Row, New York, New York, USA.

[13] Fisichelli, N.A., Frelich, L.E., Reich, P.B., Eisenhauer, N. (2012): Linking direct and indirect pathways mediating earthworms, deer, and understory composition in Great Lakes forests. - Biological Invasions 15: 1057-1066.

[14] Fitter, A.H., Fitter, R.S.R. (2002): Rapid changes in flowering time in British plants. Science 296: 1689-1691.

[15] Fredericksen, T.D., Ross, B.D., Hoffman, W., Morrison, M.L., Beyea, J., Johnson, B.N., Lester, M.B., Ross, E. (1999): Short-term understory plant community responses to timber-harvesting intensity on non-inustrial private forestlands in Pennsylvania. - Forest Ecology and Management 116: 129-139.

[16] Gilliam, F.S., Roberts, M.R. (2003): The herbaceous layer in forests of Eastern North America. - Oxford University Press. New York, USA.

[17] Gilliam, F.S., Turrill, N.L., Adam, M.B. (1995): Herbaceous-layer and overstory species in clear-cut and mature central Appalachian hardwood forests. - Ecological Applications 5: 947-955.

[18] Gleason, H.A. (1926): The individualistic concept of the plant association. - Bulletin of the Torrey Botanical Guide 53: 7-26.

[19] Gundale, M.J. ( 2002): Influence of exotic earthworms on the soil organic horizon and the rare fern Botrychium mormo. - Conservation Biology 16: 1555-1561.

[20] Hale, C. (2007): Earthworms of the Great Lakes. - Kollath and Stensaas Publishing, Duluth, MN, USA.

[21] Hale, C.M., Felich, L.E., Reich, R.B., Pastor, J. (2005): Effects of European earthworm invasion on soil characteristics in northern hardwood forests of Minnesota. - Ecosystems 8: 911-927.

[22] Hale, C.M., Frelich, L.E. Reich, P.B. (2006): Changes in hardwood forest understory plant communities in response to European earthworm invasion. -Ecology 87: 16371649.

[23] Hale, C.M., Frelich, L.E., Reich, P.B. (2004): Allometric equations for estimation of ashfree dry mass from length measurements for selected European earthworm species (Lumbricidae) in the western Great Lakes region. - American Midland Naturalist 151: 179-185. 
[24] Hale, C.M., Frelich, L.E., Reich, P.B. (2005): Exotic European earthworm invasion dynamics in northern hardwood forests of Minnesota, USA. - Ecological Applications 15: 848-860.

[25] Holdsworth, A.R., Frelich, L.E., Reich, P.B. (2007): Effects of earthworm invasion on plant species richness in northern hardwood forests. - Conservation Biology 21: 9971008.

[26] James, S.W. (1995): Systematics, biogeography, and ecology of Nearctic earthworms from eastern central, southern, and of southwestern United States - In Earthworm ecology and biogeography in North America, by editor P.F. Hendrix, 29-52. CRC Press, Boca Raton, Florida, USA.

[27] Jenkins, M.A., Parker, G.R. (1999): Composition and diversity of ground-layer vegetation in silvicultural openings of Southern Indiana forests. - The American Midland Naturalist 142: 1-16.

[28] Kern, C.C., Palik, B.J., Strong, T.F. (2006): Ground-layer plant community responses to even-age and uneven-age silvicultural treatments in Wisconsin northern hardwood forests. - Forest Ecology and Management 230: 162-170.

[29] Kotar, J. (1986): Soil of-habitat types relationships in Michigan and Wisconsin. - Journal of Soil Water Conservation 41: 348-350.

[30] Magurran, A.E. (1988): Ecological diversity and its measurements. - Croom Helm, London, UK.

[31] McCune, B. and Grace, J.B. (2002): Analysis of ecological communities. - MjM Software Design, Gleneden Beach, Oregon, USA.

[32] McCune, B. Mefford, M.J. PC-ORD. (2011): Multivariate Analysis of Ecological Data. Version 5. - MjM Software Design, Gleneden Beach, Oregon, USA.

[33] Metzger, F., Schultz, J. (1981): Spring ground layer vegetation 50 years after harvesting in northern hardwood forests. - American Midland Naturalist 105: 44-50.

[34] Miller-Rushing, A.J., Primack, R.B. (2008): Global warming and flowering times in Thoreau's Concord: A community perspective. - Ecology 89: 332-341.

[35] Muller, R.N., Bormann, F.H., 1976. Role of Erythronium americanum Ker. in energy flow and nutrient dynamics of a northern hardwood forest ecosystem. Science 193, 11261128 .

[36] Myers, P., Lundrigan, B.L., Hoffman, S.M.G., Haraminac, A.P., Seto, S.H. (2009): Climate-induced changes in the small mammal communities of the northern Great Lakes region. - Global Change Biology 15: 1434-1454.

[37] Newcomb, L. (1989): Newcomb's wildflower guide. - Little, Brown and Co, New York, USA.

[38] Oliver, C.D., Larson, B.C. (1996): Forest stand dynamics: Update edition. - John Wiley and Sons, Inc, New York, USA.

[39] Pfister, R.D. (1989): Basic concepts of using vegetation to build a site classification system. Land classification based on vegetation application for resource management. Moscow, ID, USA.

[40] Pfister, R.D., Arno, S.F. (1980): Classifying forest habitat types based on potential climax vegetation. - Forest Science 26: 52-70.

[41] PRISM Climate Group (2004): PRISM Climate Database - Oregon State University, http://prism.oregonstate.edu

[42] Powers, M.D., Nagel, L.M. (2008): Disturbance dynamics influence Carex pensylvanica abundance in a northern hardwood forest. -The Journal of the Torrey Botanical Society 135: 317-327.

[43] R Development Core Team (2011): R: A language and environment for statistical computing. - In: R Foundation for Statistical Computing, Vienna, Austria. ISBN 3900051-07-0, URL http://www.R-project.org/.

[44] Roberts, M.R., Gilliam, F.S. (1995): Patterns and mechanisms of plant diversity in forested ecosystems: implications for forest management. - Ecological Applications 5: 
969-977.

[45] Scheller, R.M., Mladenoff, D.J. (2002): Understory species patterns and diversity in oldgrowth and managed northen hardwood forests. - Ecological Applications 12: 1329-1343.

[46] Scheu, S., Parkinson, D. (1994): Effects of earthworms on nutrient dynamics, carbon turnover, and microorganisms in soils from cool temperate forests of the Canadian Rocky Mountains - laboratory studies. - Applied Soil Ecology 1:113-125.

[47] Schwartz, M.D., Reiter, B.E. (2000): Changes in North American spring. -International Journal of Climatology 20: 929-932.

[48] Service, Soil Conservation. (2006): Soil survey of Keewenaw County area Michigan. USDA Soil Conservation Service, USA.

[49] Service, Soil Conservation. (2010): Soil survey of Ontonagon County area Michigan. USDA Soil Conservation Service, USA.

[50] Soil Conservation Service. (1991): Soil survery of Houghton County area Michigan. USDA Soil Conservation Service, USA.

[51] Suárez, E.R. Fahey, T.J. Groffman, P.M., Bohlen, P.J., Fisk, M.C. (2004): Effects of exotic earthworms on soil phosphorous cycling in two broadleaf temperate forests. Ecosystems 7: 28-44.

[52] Tomlin, A.D., Shipitalo, M.J., Edwards, W.M. Protz, R. (1995): Earthworms and their influence on soil structure and infiltration. - In Earthworm ecology and biogeography in North America, by editor P.R. Hendrix, 159-184, CRC Press, Boca Raton, FL, USA.

[53] Tukey, J.W. (1953): The problem of multiple comparison. - Unplished report. Princeton University, Princeton, USA.

[54] USDA, NRCS. The PLANTS Database. March 21, 2011. http://plants.usda.gov (accessed March 27, 2014).

[55] Voss, E.G. (1985): Michigan Flora, Part II. Dicots (Saururaceae-Cornaceae). -Cranbrook Institute of Science Bulletin 59 and University of Michigan Herbarium, Ann Arbor, Michigan, USA.

[56] Voss, E.G. (1996): Michigan Flora. Part III. Dicots (Pyrolaceae-Compositae). Cranbrook Institute of Science Bulletin 61 and University of Michigan Herbarium, Ann Arbor, Michigan, USA.

[57] Walther, G.R., Post, E., Convey, P., Menzel, A., Parmesan, C., Beebee, T.J.C., Fromentin, J.M., Hoegh-Guldberg, O., Bairlein, F. (2002): Ecological responses to recent climate change. - Nature 416: 389-395.

[58] Watkins, R.Z., J.Q. Chen, J. Pickens, and K.D. Brosofske. (2003): Effects of forest roads on understory plants in a managed hardwood landscape. - Conservation Biology 17: 411419.

[59] Wiegmann, S.M. and D. M. Waller. (2006): Fifty years of change in northern upland forest understories: Identity and traits of "winner" and "loser" plant species. Biological Conservation 129: 109-123.

[60] Winthers, E., Fallon, D., Haglund, J., Demeo, T., Nowacki, G., Tart, D., Ferwerda, M., Robertson, G., Rorick, A., Cleland, D.T., Robbie, W. (2005): Terrestrial Ecological Unit inventory technical guide. - Department of Agriculture, Forest Service, Washington Office, Ecosystem Management Coordination Staff. 245p, Washington D.C., U.S.

[61] Wolf, A.T., Parker, L., Fewless, FG., Corio, K., Sundance, J., Howe, R., Gentry, H. (2008): Impacts of summer versus winter logging on understory vegetation in the Chequamegon-Nicolet National Forest. - Forest Ecology and Management 245: 35-45.

[62] Zenner, E.K., Kabrick, J.M., Jensen, R.G., Peck, J.E., Grabner, J.K. (2006): Responses of ground flora to a gradient of harvest intensity in the Missouri Ozarks. - Forest Ecology and Management 222: 326-334. 


\section{APPENDIX}

\section{Appendix A}

Appendix A.1 Full list of species observed in 2000 and 2010.

\begin{tabular}{|c|c|c|c|c|}
\hline Scientific name & Common Name & Family & Growth Form & Shade Tolerance \\
\hline Acer pensylvanicum $\mathrm{L}$. & striped maple & Sapindaceae & Shrub & Tolerant \\
\hline Acer spicatum Lam. & mountain maple & Sapindaceae & Shrub & Tolerant \\
\hline Achillea millefolium L. * & common yarrow & Asteraceae & Forb/herb & Intermediate \\
\hline Actaea spp. & Baneberries & Ranunculaceae & Forb/herb & Tolerant \\
\hline Adiantum pedatum $\mathrm{L}$. & northern maidenhair fern & Pteridaceae & Forb/herb & Tolerant \\
\hline Allium tricoccum Aiton & ramp & Liliaceae & Forb/herb & Tolerant \\
\hline Amaranthus retroflexus $\mathrm{L}$. & redroot amaranth & Amaranthaceae & Forb/herb & Intolerant \\
\hline Amelanchier spp. & Serviceberry & Rosaceae & Shrub & Tolerant \\
\hline Amphicarpaea bracteata (L.) Fernald & American hogpeanut & Fabaceae & Vine & Intermediate \\
\hline Anemone quinquefolia $\mathrm{L}$. & wood anemone & Ranunculaceae & Forb/herb & Tolerant \\
\hline Antennaria neglecta Green & field pussytoes & Asteraceae & Forb/herb & Intolerant \\
\hline Apocynum androsaemifolium $\mathrm{L}$. & spreading dogbane & Apocynaceae & Forb/herb & Intermediate \\
\hline Aquilegia canadensis $\mathrm{L}$. & red columbine & Ranunculaceae & Forb/herb & Intermediate \\
\hline Aralia nudicaulis L. & wild sarsaparilla & Araliaceae & Forb/herb & Tolerant \\
\hline Aralia racemosa $\mathrm{L}$. & American spikenard & Araliaceae & $\begin{array}{l}\text { Subshrub } \\
\text { Forb/herb }\end{array}$ & Tolerant \\
\hline Arctostaphylos uva-ursi (L.) Spreng. & kinnikinnick & Ericaceae & Shrub & Intermediate \\
\hline Arisaema triphyllum (L.) Schott & Jack in the pulpit & Araceae & Forb/herb & Tolerant \\
\hline Asarum canadense $\mathrm{L}$. & Canadian wildginger & Aristolochiaceae & Forb/herb & Tolerant \\
\hline Athyrium filix-femina (L.) Roth & common ladyfern & Dryopteridaceae & Forb/herb & Tolerant \\
\hline Barbarea vulgaris W.T. Aiton * & garden yellowrocket & Brassicaceae & Forb/herb & Intolerant \\
\hline Berberis thunbergii DC. * & Japanese barberry & Berberidaceae & Shrub & Intolerant \\
\hline Botrychium virginianum (L.) Sw. & rattlesnake fern & Ophioglossaceae & Forb/herb & Tolerant \\
\hline $\begin{array}{l}\text { Cardamine bulbosa (Schreb. Ex Muhl.) } \\
\text { Britton, Sterns \& Poggenb. }\end{array}$ & bulbous bittercress & Brassicaceae & Forb/herb & Tolerant \\
\hline Caulophyllum thalictroides (L.) Michx. & blue cohosh & Berberidaceae & Forb/herb & Tolerant \\
\hline Chimaphila umbellata (L.) W.P.C. Barton & pipsissewa & Pyrolaceae & Subshrub & Tolerant \\
\hline Circaea alpina $(\mathrm{L})$. & small enchanter's nightshade & Onagraceae & Forb/herb & Tolerant \\
\hline $\begin{array}{l}\text { Circaea quadrisulcata (L.) Asch. \& } \\
\text { Magnus }\end{array}$ & $\begin{array}{l}\text { broadleaf enchanter's } \\
\text { nightshade }\end{array}$ & Onagraceae & Forb/herb & Tolerant \\
\hline Cirsium arvense (L.) Scop. $*$ & Canada thistle & Asteraceae & Forb/herb & Intolerant \\
\hline Cladina mitis (Sandst.) Hustich & reindeer lichen & Cladoniaceae & Lichen & Intolerant \\
\hline Claytonia virginica $\mathrm{L}$. & Virginia springbeauty & Portulaceae & Forb/herb & Intermediate \\
\hline Clintonia borealis (Aiton) Raf. & bluebead & Liliaceae & Forb/herb & Intolerant \\
\hline Comptonia peregrina (L.) J.M. Coult. & sweet fern & Myricaceae & Shrub & Intermediate \\
\hline Coptis groenlandica (L.) Salisb. & threeleaf goldthread & Ranunculaceae & Forb/herb & Tolerant \\
\hline Cornus alternifolia L. f. & alternateleaf dogwood & Cornaceae & Shrub & Tolerant \\
\hline Cornus canadensis $\mathrm{L}$. & bunchberry dogwood & Cornaceae & Forb/herb & Tolerant \\
\hline Cornus racemosa Lam. & gray dogwood & Cornaceae & Shrub & Tolerant \\
\hline Cornus stolonifera Michx. & redosier dogwood & Cornaceae & Shrub & Intolerant \\
\hline Corylus cornuta Marshall & beaked hazelnut & Betulaceae & Shrub & Tolerant \\
\hline Crataegus spp. & Hawthorn & Rosaceae & Shrub & Midtolerant \\
\hline Cuphea viscosissima Jacq. & blue waxweed & Lythraceae & Forb/herb & Intolerant \\
\hline Cypripedium acaule Aiton & pink lady's slipper & Orchidaceae & Forb/herb & Intermediate \\
\hline $\begin{array}{l}\text { Desmodium glutinosum (Muhl. ex Willd.) } \\
\text { Alph. Wood }\end{array}$ & pointedleaf ticktrefoil & Fabaceae & Forb/herb & Tolerant \\
\hline Dicentra cucullaria (L.) Bernh. & dutchman's breeches & Fumariaceae & Forb/herb & Intermediate \\
\hline Diervilla lonicera Mill. & northern bush honeysuckle & Caprifoliaceae & Shrub & Intermediate \\
\hline Dirca palustris L. & eastern leatherwood & Thymelaeaceae & Shrub & Tolerant \\
\hline Dryopteris spinulosa (O.F. Müll.) Watt & spinulose shield fern & Dryopteridaceae & Forb/herb & Tolerant \\
\hline Epifagus virginiana (L.) W.P.C. Barton & beechdrops & Orobanchaceae & Forb/herb & Tolerant \\
\hline Epigaea repens $\mathrm{L}$. & trailing arbutus & Ericaceae & Subshrub & Tolerant \\
\hline Epipactis helleborine (L.) Crantz * & broadleaf helleborine & Orchidaceae & Forb/herb & Midtolerant \\
\hline Equisetum spp. & Horsetail & Equisetaceae & Equisetum & Midtolerant - Intolerant \\
\hline Erigeron spp. & Fleabane & Asteraceae & Forb/herb & Intolerant \\
\hline $\begin{array}{l}\text { Erythronium americanum Ker Gawl. } \\
\text { subsp. americanum }\end{array}$ & yellow trout lily & Liliaceae & Forb/herb & Tolerant \\
\hline Eupatorium purpureum $\mathrm{L}$. & green-stemmed Joe-Pye-weed & Asteraceae & Forb/herb & Intermediate \\
\hline Eurybia macrophylla (L.) Cass. & bigleaf aster & Asteraceae & Forb/herb & Tolerant \\
\hline Fallopia convolvulus (L.) A.Löve * & black-bindweed & Polygonaceae & Vine & Intolerant \\
\hline Fragaria spp. & Strawberry & Rosaceae & Shrub & Midtolerant \\
\hline Frangula alnus Mill. * & glossy buckthorn & Rhamnaceae & Shrub & Intolerant \\
\hline Galeopsis tetrahit L. * & brittlestem hempnettle & Lamiaceae & Forb/herb & Intolerant \\
\hline Galium boreale $\mathrm{L}$. & northern bedstraw & Rubiaceae & Forb/herb & Intermediate \\
\hline
\end{tabular}


Appendix A.1 Continued.

\begin{tabular}{|c|c|c|c|c|}
\hline Scientific name & Common Name & Family & Growth Form & Shade Tolerance \\
\hline Galium triflorum Michx. & fragrant bedstraw & Rubiaceae & $\begin{array}{l}\text { Forb/herb } \\
\text { Vine }\end{array}$ & Tolerant \\
\hline $\begin{array}{l}\text { Gaultheria hispidula (L.) Muhl. } \\
\text { ex Bigelow }\end{array}$ & creeping snowberry & Ericaceae & $\begin{array}{l}\text { Subshrub } \\
\text { Shrub }\end{array}$ & Tolerant \\
\hline Gaultheria procumbens $\mathrm{L}$. & wintergreen & Ericaceae & Subshrub & Tolerant \\
\hline $\begin{array}{l}\text { Gaylussacia baccata (Wangenh.) K. } \\
\text { Koch }\end{array}$ & black huckleberry & Ericaceae & Shrub & Tolerant \\
\hline Geranium maculatum $\mathrm{L}$. & spotted geranium & Geraniaceae & Forb/herb & Intermediate \\
\hline Grasses \& Sedges & grasses \& sedges & - & Graminoid & - \\
\hline Gymnocarpium dryopteris (L.) Newman & western oak fern & Dryopteridaceae & Forb/herb & Tolerant \\
\hline Hamamelis virginiana $\mathrm{L}$. & American witchhazel & Hamamelidaceae & Shrub & Intermediate \\
\hline Helenium nudiflorum Raf. & purplehead sneezeweed & Asteraceae & Forb/herb & Intolerant \\
\hline Heliopsis helianthoides (L.) Sweet & smooth oxeye & Asteraceae & Forb/herb & Intolerant \\
\hline Hepatica acutiloba DC. & sharplobe hepatica & Ranunculaceae & Forb/herb & Tolerant \\
\hline Hepatica americana (DC.) Ker Gawl. & roundlobe hepatica & Ranunculaceae & Forb/herb & Tolerant \\
\hline Hieracium aurantiacum L. * & orange hawkweed & Asteraceae & Forb/herb & Intolerant \\
\hline Hieracium paniculatum $\mathrm{L}$. & Allegheny hawkweed & Asteraceae & Forb/herb & Tolerant \\
\hline Hieracium pilosella $\mathrm{L}$. var. pilosella $*$ & mouseear hawkweed & Asteraceae & Forb/herb & Intolerant \\
\hline Hieracium venosum $\mathrm{L}$. & rattlesnakeweed & Asteraceae & Forb/herb & Intermediate \\
\hline Huperzia lucidula (Michx.) Trevis. & shining clubmoss & Lycopodiaceae & Subshrub & Intermediate \\
\hline Hydrophyllum virginianum $\mathrm{L}$. & eastern waterleaf & Hydrophyllaceae & Forb/herb & Intermediate \\
\hline Hypericum perforatum $\mathrm{L} . *$ & common St. Johnswort & Clusiaceae & Forb/herb & Intolerant \\
\hline Hypochaeris radicata $\mathrm{L} . *$ & hairy cat's ear & Asteraceae & Forb/herb & Intolerant \\
\hline Impatiens capensis Meerb. & jewelweed & Balsaminaceae & Forb/herb & Tolerant \\
\hline Juniperus communis L. & common juniper & Cupressaceae & Shrub & Intolerant \\
\hline Laportea canadensis (L.) Weddell & Canadian woodnettle & Urticaceae & Forb/herb & Tolerant \\
\hline Lapsana communis (L.) * & common nipplewort & Asteraceae & Forb/herb & Intolerant \\
\hline Leucanthemum vulgare (Lam.)* & oxeye daisy & Asteraceae & Forb/herb & Intermediate \\
\hline $\begin{array}{l}\text { Linnaea borealis L. subsp. americana } \\
\text { (Forbes) Hultén ex R.T.Clausen }\end{array}$ & twinflower & Caprifoliaceae & Forb/herb & Tolerant \\
\hline Lithospermum canescens (Michx.) Lehm. & hoary puccoon & Boraginaceae & Forb/herb & Intermediate \\
\hline Lonicera canadensis W. Bartram ex Marshall & American fly honeysuckle & Caprifoliaceae & Shrub & Intermediate \\
\hline Lycopodium annotinum $\mathrm{L}$. & stiff clubmoss & Lycopodiaceae & $\begin{array}{l}\text { Subshrub } \\
\text { Forb/herb }\end{array}$ & Tolerant \\
\hline Lycopodium clavatum $\mathrm{L}$. & Running clubmoss & Lycopodiaceae & $\begin{array}{l}\text { Subshrub } \\
\text { Forb/herb }\end{array}$ & Intermediate \\
\hline Lycopodium complanatum $\mathrm{L}$. & groundcedar & Lycopodiaceae & $\begin{array}{l}\text { Subshrub } \\
\text { Forb/herb }\end{array}$ & Tolerant \\
\hline Lycopodium obscurum $\mathrm{L}$. & rare clubmoss & Lycopodiaceae & $\begin{array}{l}\text { Subshrub } \\
\text { Forb/herb }\end{array}$ & Tolerant \\
\hline Lysimachia quadrifolia $\mathrm{L}$. & whorled yellow loosestrife & Primulaceae & Forb/herb & Intermediate \\
\hline Maianthemum canadense Desf. & Canada mayflower & Liliaceae & Forb/herb & Tolerant \\
\hline $\begin{array}{l}\text { Maianthemum racemosum (L.) Link } \\
\text { ssp. racemosum }\end{array}$ & feathery false lily of the valley & Liliaceae & Forb/herb & Intermediate \\
\hline Maianthemum stellatum (L.) Link & starry false lily of the valley & Liliaceae & Forb/herb & Intermediate \\
\hline Matteuccia struthiopteris (L.) Todaro & ostrich fern & Dryopteridaceae & Forb/herb & Tolerant \\
\hline Medeola virginiana $\mathrm{L}$. & indian cucumber-root & Liliaceae & Forb/herb & Tolerant \\
\hline Melampyrum lineare Desr. & narrow-leaf cow-wheat & Scrophulariaceae & Forb/herb & Intermediate \\
\hline Mitchella repens $\mathrm{L}$. & partridgeberry & Rubiaceae & $\begin{array}{l}\text { Subshrub } \\
\text { Forb/herb }\end{array}$ & Tolerant \\
\hline Mitella diphylla $\mathrm{L}$. & twoleaf miterwort & Saxifragaceae & Forb/herb & Intermediate \\
\hline Mitella nuda $\mathrm{L}$. & naked miterwort & Saxifragaceae & Forb/herb & Tolerant \\
\hline $\begin{array}{l}\text { Monotropa uniflora } \mathrm{L} . \\
\text { moss }\end{array}$ & Indian-pipe & Monotropaceae & Forb/herb & Tolerant \\
\hline Myosotis scorpioides L. * & true forget-me-not & Boraginaceae & Forb/herb & Intermediate \\
\hline Myosotis verna Nutt. & spring forget-me-not & Boraginaceae & Forb/herb & Intermediate \\
\hline Onoclea sensibilis $\mathrm{L}$. & sensitive fern & Dryopteridaceae & Forb/herb & Tolerant \\
\hline Osmorhiza claytoni (Michx.) C.B. Clarke & Clayton's sweetroot & Apiaceae & Forb/herb & Tolerant \\
\hline Osmunda cinnamomea $\mathrm{L}$. & cinnamon fern & Osmundaceae & Forb/herb & Tolerant \\
\hline Osmunda claytoniana $\mathrm{L}$. & interrupted fern & Osmundaceae & Forb/herb & Tolerant \\
\hline Oxalis montana Raf. & common woodsorrel & Oxalidaceae & Forb/herb & Tolerant \\
\hline Panax trifolius $\mathrm{L}$. & dwarf ginseng & Araliaceae & Forb/herb & Tolerant \\
\hline Parthenium integrifolium Britton & wild quinine & Asteraceae & Forb/herb & Intermediate \\
\hline Parthenocissus quinquefolia (L.) Planch. & Virginia creeper & Vitaceae & Vine & Intermediate \\
\hline Pedicularis canadensis $\mathrm{L}$. & Canadian lousewort & Scrophulariaceae & $\begin{array}{l}\text { Subshrub } \\
\text { Forb/herb }\end{array}$ & Tolerant \\
\hline $\begin{array}{l}\text { Petasites frigidus (L.) Fr. var. palmatus } \\
\text { (Aiton) Cronquist }\end{array}$ & northern sweet-colt's-foot & Asteraceae & Forb/herb & Intermediate \\
\hline Phegopteris connectilis (Michx.) Watt & long beechfern & Thelypteridaceae & Forb/herb & Tolerant \\
\hline
\end{tabular}


Appendix A.1 Continued.

\begin{tabular}{|c|c|c|c|c|}
\hline Scientific name & Common Name & Family & Growth Form & Shade Tolerance \\
\hline Phryma leptostachya $\mathrm{L}$. & American lopseed & Verbenaceae & Forb/herb & Tolerant \\
\hline Plantago lanceolata $\mathrm{L} . *$ & narrowleaf plantain & Plantaginaceae & Forb/herb & Intolerant \\
\hline Podophyllum peltatum $\mathrm{L}$. & mayapple & Berberidaceae & Forb/herb & Intolerant \\
\hline Polygala paucifolia Willd. & gaywings & Polygonaceae & Forb/herb & Tolerant \\
\hline Polygonatum pubescens (Willd.) Pursh & hairy Solomon's seal & Liliaceae & Forb/herb & Tolerant \\
\hline Prenanthes alba $\mathrm{L}$. & white rattlesnakeroot & Asteraceae & Forb/herb & Intermediate \\
\hline Prunella vulgaris $\mathrm{L}$. & common selfheal & Lamiaceae & Forb/herb & Intermediate \\
\hline Prunus serotina Ehrh. & black cherry & Rosaceae & Shrub & Intolerant \\
\hline Prunus virginiana $\mathrm{L}$. & chokecherry & Rosaceae & Shrub & Intolerant \\
\hline Pteridium aquilinum (L.) Kuhn & western brackenfern & Dennstaedtiaceae & Forb/herb & Tolerant \\
\hline Pyrola elliptica Nutt & waxflower shinleaf & Pyrolaceae & Subshrub & Tolerant \\
\hline Pyrola spp. & Shinleafs & Pyrolaceae & Forb/herb & Tolerant \\
\hline Ranunculus abortivus L. & littleleaf buttercup & Ranunculaceae & Forb/herb & Tolerant \\
\hline $\begin{array}{l}\text { Ranunculus recurvatus Poir. } \\
\text { var. recurvatus }\end{array}$ & hooked buttercup & Ranunculaceae & Forb/herb & Tolerant \\
\hline Ribes cynosbati $\mathrm{L}$. & eastern prickly gooseberry & Grossulariaceae & Shrub & Intolerant \\
\hline Rosa spp. & Rose & Rosaceae & Shrub & Intolerant \\
\hline Rubus spp. & Raspberry & Rosaceae & Shrub & Intolerant \\
\hline Rumex acetosella* & common sheep sorrel & Polygonaceae & Forb/herb & Intolerant \\
\hline Sambucus canaadensis L. var. canadensis & American black elderberry & Caprifoliaceae & Shrub & Intolerant \\
\hline $\begin{array}{l}\text { Sambucus racemosa L. subsp. pubens } \\
\text { (Michx.) House var. pubens (Michx.) Koehne }\end{array}$ & red elderberry & Caprifoliaceae & Shrub & Intermediate \\
\hline Sanguinaria canadensis L. & bloodroot & Papaveraceae & Forb/herb & Tolerant \\
\hline Sanicula marilandica $\mathrm{L}$. & black snake-root & Apiaceae & Forb/herb & Tolerant \\
\hline Senecio obovatus Muhl. Ex Willd. & roundleaf ragwort & Asteraceae & Forb/herb & Midtolerant \\
\hline Smilax herbacea $\mathrm{L}$. & smooth carrionflower & Smilacaceae & $\begin{array}{l}\text { Vine } \\
\text { Forb/herb }\end{array}$ & Tolerant \\
\hline Smilax tamnoides $\mathrm{L}$. & bristly greenbrier & Smilacaceae & $\begin{array}{l}\text { Shrub } \\
\text { Vine }\end{array}$ & Intermediate \\
\hline Solanum dulcamara $\mathrm{L} . *$ & climbing nightshade & Solanaceae & Vine & Intermediate \\
\hline Solidago flexicaulis $\mathrm{L}$. & zigzag goldrenrod & Asteraceae & Forb/herb & Intermediate \\
\hline $\begin{array}{l}\text { Streptopus lanceolatus (Aiton) Reveal var. } \\
\text { Longipes (Fernald) Reveal }\end{array}$ & rosey twistedstalk & Liliaceae & Forb/herb & Tolerant \\
\hline $\begin{array}{l}\text { Symplocarpus foetidus (L.) Salisb. ex W.P.C. } \\
\text { Barton }\end{array}$ & skunk cabbage & Araceae & Forb/herb & Tolerant \\
\hline Taraxacum officinale F.H. Wigg. * & common dandelion & Asteraceae & Forb/herb & Intermediate \\
\hline Taxus canadensis Marshall & Canada yew & Taxaceae & Shrub & Tolerant \\
\hline Thalictrum dioicum $\mathrm{L}$. & early meadow-rue & Ranunculaceae & Forb/herb & Intermediate \\
\hline Tiarella cordifolia $\mathrm{L}$. & foamflower & Saxifragaceae & Forb/herb & Intermediate \\
\hline $\begin{array}{l}\text { Toxicodendron radicans (L.) Kuntza subsp. } \\
\text { negundo (Greene) Gillis }\end{array}$ & eastern poison ivy & Anacardiaceae & $\begin{array}{l}\text { Forb/herb } \\
\text { Vine }\end{array}$ & Intermediate \\
\hline Trientalis borealis Raf. subsp. borealis & starflower & Primulaceae & Forb/herb & Tolerant \\
\hline Trifolium pratense $\mathrm{L} . *$ & red clover & Fabaceae & Forb/herb & Intolerant \\
\hline Trillium cernuит $\mathrm{L}$. & nodding trillium & Liliaceae & Forb/herb & Tolerant \\
\hline Trillium grandiflorum (Michx.) Salisb. & white trillium & Liliaceae & Forb/herb & Tolerant \\
\hline Uvularia grandiflora $\mathrm{Sm}$. & largeflower bellwort & Liliaceae & Forb/herb & Tolerant \\
\hline Uvularia sessilifolia $\mathrm{L}$. & sessileleaf bellwort & Liliaceae & Forb/herb & Intermediate \\
\hline Vaccinium angustifolium Aiton & lowbush blueberry & Ericaceae & Shrub & Intolerant \\
\hline Vaccinium myrtilloides Michx. & velvetleaf huckleberry & Ericaceae & Shrub & Intermediate \\
\hline Verbascum thapsus L. * & common mullein & Scrophulariaceae & Forb/herb & Intolerant \\
\hline Veronica arvensis L. * & corn speedwell & Scrophulariaceae & Forb/herb & Intolerant \\
\hline Veronica chamaedrys L.* & birdeye's speedwell & Scrophulariaceae & Forb/herb & Intolerant \\
\hline Veronica officinalis L. * & Common Gypsyweed & Scrophulariaceae & Forb/herb & Intolerant \\
\hline Viburnum acerifolium $\mathrm{L}$. & mapleleaf viburnnum & Caprifoliaceae & Shrub & Tolerant \\
\hline Viburnum lentago L. & nannyberry & Caprifoliaceae & Shrub & Tolerant \\
\hline Viburnum rafinesqueanum Schult. & downy arrowwood & Caprifoliaceae & Shrub & Tolerant \\
\hline Viola canadensis L. & Canadian white violet & Violaceae & Forb/herb & Tolerant \\
\hline Viola conspersa Schrank & dog violet & Violaceae & Forb/herb & Intermediate \\
\hline $\begin{array}{l}\text { Viola macloskey F.E.Lloyd subsp. pallens } \\
\text { (Banks ex Ging.) M.S.Baker }\end{array}$ & wild white violet & Violaceae & Forb/herb & Intermediate \\
\hline Viola pubescens Aiton & downy yellow violet & Violaceae & Forb/herb & Tolerant \\
\hline Viola sororia Willd. & common blue violet & Violaceae & Forb/herb & Intermediate \\
\hline Vitis riparia Michx. & riverbank grape & Vitaceae & Forb/herb & Intermediate \\
\hline $\begin{array}{l}\text { Waldsteinia fragarioides (Michx.) Tratt. } \\
\text { subsp. fragarioides }\end{array}$ & Appalachian barren strawberry & Rosaceae & Forb/herb & Tolerant \\
\hline $\begin{array}{l}\text { * Invasive species } \\
\text { woodlands, woods }=\text { tolerant } \\
\text { open woods, thickets }=\text { midtolerant } \\
\text { waste places, roadsides,meadows }=\text { intolerant }\end{array}$ & & & & \\
\hline
\end{tabular}

\section{ELECTRONIC APPENDIX:}

This article has an electronic appendix with basic data. 